\title{
Pelatihan Pengasuhan untuk Meningkatkan Pemahaman dan Kualitas Pengasuhan Orang Tua Anak GPP/H
}

Ratna Yunita Setiyani S, Indria Laksmi Gamayanti dan Siti Urbayatun

Puskesmas Kraton, Jl. Musikanan KT II/457 ; Tumbuh Kembang Anak RS. Dr. Sardjito, Jl. Kesehatan No. 1, Sekip, Daerah Istimewa Yogyakarta 55284; Fakultas Psikologi, Universitas Ahmad Dahlan, Jl. Kapas 9, Semaki Yogyakarta.finumatin@yahoo.com

\begin{abstract}
This research was aimed to verify whether parenting training could improve the understanding about ADHD and quality care on parents of preschool children with ADHD. The research design was quasi experimental with non-randomized pretest-posttest control group design. The participants on this study were six people that were parents of preschool children with ADHD. This study took place in Jogja Citra preschool-kindergarten-day care, Pleret, Bantul. This research used Wilcoxon Mann Whitney and Kruskal Wallis as statistical analysis. The findings indicate that parenting training could improve parents understanding on ADHD and also improving the quality care of parents towards preschool children with ADHD. The data processing shows $0.039<0.05$ for significance level of the understanding towards ADHD and $0.039<0.05$ for quality care. The significance level of Kruskal Wallis hypothetical test is $0.020<0.05$.
\end{abstract}

Keywords: parenting training, understanding on ADHD, quality care

\begin{abstract}
ABSTRAK
Penelitian ini bertujuan untuk menguji apakah pelatihan pengasuhan dapat meningkatkan pemahaman tentang GPP/H dan pengasuhan yang berkualitas pada orang tua anak prasekolah yang memiliki anak dengan GPP/H. Penelitian ini menggunakan rancangan quasi eksperimental dengan desain nonrandomized pretest-posttest control group design. Subjek padapenelitianini berjumlah 6 orang yang merupakan pasangan orang tua (ayah dan ibu) anak prasekolah yang memiliki anak dengan GPP/H. Tempat penelitian dilakukan di KB-TK-TPA Jogja Citra, Pleret, Bantul. Dianalisis dengan uji statistik Wilcoxon Mann Whitney dan Kruskal Wallis.Hasil penelitian menunjukkan bahwa pelatihan pengasuhan terbukti dapat meningkatkan pemahaman orang tua tentang $\mathrm{GPP} / \mathrm{H}$ dan meningkatkan kualitas pengasuhan orang tua kepada anak prasekolah dengan GPP/H. Hasil pengolahan data menunjukkan taraf signifikansi 0,039 < 0,05 untuk pemahaman tentang $\mathrm{GPP} / \mathrm{H}$, dan 0,039<0,05 untuk pengasuhan yang berkualitas. Uji hipotesis dengan Kruskal Wallis menunjukkan taraf signifikansi sebsar 0,020<0,05.
\end{abstract}

Kata kunci : pelatihan pengasuhan, pemahaman tentang GPP/H, kualitas pengasuhan 


\section{PENDAHULUAN}

Saat ini mulai banyak muncul keluhankeluhan dan kesulitan pada anak terutama yang terkait dengan kesulitan belajar, seperti kesulitan menyesuaikan diri dengan lingkungan, kesulitan belajar mengenal angka, huruf, menulis, duduk diam di kelas dan fokus pada sesuatu/ berkonsentrasi.Kesulitan pada anak terutama yang terkait dengan belajar, kesulitan dalam mengontrol gerakan, dan hiperaktivitas dapat menimbulkan masalah di sekolah selama masa kanak-kanak dan remaja (Gromisch, 2013).

Martin(dalam Barkley, 2006) mengatakan bahwa lingkungan melihat anak GPP/H sebagai anak yang memiliki sikap tidak kooperatif, kurang konsentrasi, "susah diatur”, dan tidak mau diam. Betapapun kerasnya usaha orang tua dalam mengarahkan, anak GPP/H terus saja melamun, tidak mampu untuk duduk tenang, mengganggu, mengamuk, mengabaikan tanggung jawabnya dan tidak mampu menjalin hubungan pertemanan, apalagi persahabatan dengan orang lain. Kondisi hubungan relasi sosial yang buruk ini menimbulkan kekhawatiran pada orang tua. Catatan-catatan dari guru di taman bermain anak, keluhan-keluhan dari orang tua siswa lain menambah peningkatan kondisi stres pada orang tua yang memiliki anak GPP/H. Bahkan dapat mengakibatkan persepsi orang tua terhadap dirinya sendiri menjadi buruk dan merasa tidak mampu berperan sebagai orang tua yang baik. Hal ini menarik bagi peneliti mengingat yang diutarakan Barkley (2006) bahwa kurangnya pengetahuan orang tua mengenai keterbatasan anak dalam mengarahkan perilaku anak dan rentang perhatian mereka, membuat pola perilaku orang tua terhadap anak menjadi tidak tepat.

Menurut Gomez \& Sanson (Briesmeister \& Schaefer, 2007) kondisi stres orang tua dalam menangani perilaku anak GPP/H dapat berimbas pada rendahnya kualitas pengasuhan yang diberikan orang tua terhadap anak GPP/H. Orang tua menjadi banyak mengontrol, kurang responsif terhadap pertanyaan anak, sering memerintah, kurang konsisten dan memberikan hukuman sebagai metode yang dianggap mampu mendisiplinkan anak, serta hanya sedikit memberikan perhatian terhadap perilaku yang positif. Akibatnya gejala GPP/H terus berlanjut dan berkembang berbagai gejala.

Orang tua sering bingung dan merasa kesulitan merawat seorang anak GPP/H. Orang tua dan anak akan terjebak dalam lingkaran dari konfrontasi dan konflik. Ini akan memicu perasaan bersalah, terutama ketika orang tua mengatakan dan melakukan hal-hal yang sebenarnya tidak boleh dikatakan dan dilakukan oleh orang tua. Seluruh keluarga akhirnya sering berada pada titik kritis, sehingga setiap anggota keluarga saling menyalahkan atas terjadinya masalah itu, walaupun mungkin dalam hati kecil masing-masing merasa bahwa dirinyalah yang mungkin bersalah (Pentecost, 2004).

Menurut Flanagen (2005) permasalahan lain yang timbul akibat perilaku anak dengan GPP/H ini adalah, orang tua pada umumnya sulit untuk memahami dan menerima anak. Orang tua menjadi cemas, kecewa dan biasanya bersikap menuntut atau menekan anak. Permasalahan menjadi kusut seperti lingkaran setan, yang sebenarnya dapat dihindari. Banyak orang tua yang kelelahan karena berusaha mengatasi perilaku anak-anak mereka dan mendekati depresi setelah mengetahui bahwa anaknya mengalami GPP/H.

Studi awal yang dilakukan oleh peneliti (April-Mei 2012) mengenai permasalahan orang tua dalam menghadapi perilaku anak prasekolah dengan GPP/H, di Dusun Citra Pleret Bantul, Yogyakarta terhadap tiga pasangan orang tua (yang terdiri dari tiga ayah dan tiga ibu), melalui wawancara dan observasi di rumah dan sekolah didapatkan kesimpulan bahwa orang tua tampak belum memiliki informasi yang cukup mengenai keterbatasan anak dengan GPP/H. Hal ini didapat saat peneliti bertanya kepada orangtua, apakah orang tua tahu apa yang terjadi pada 
anaknya, apakah penyebabnya, dan bagaimana cara orang tua menangani perilaku yang dimunculkan oleh anak. Hampir seluruh orang tua menjawab bahwa hal ini sudah sering terjadi dan orang tua menjadi bingung harus bagaimana dalam mengasuh anak. Selama ini cara menangani perilaku anak biasanya dilakukan dengan melarang, memberi ancaman, marahmarah, menyembunyikan anak dari orang lain hingga orang tua merasa stres dan kesal. Semua orang tua yang diwawancara mengatakan bahwa anaknya akan diberi hukuman fisik jika menampilkan perilaku yang tidak diinginkan orang tua, seperti melawan, malas, tidak dapat diatur atau diarahkan, terus menerus membuat kekacauan baik di rumah maupun di lingkungannya, perilakunya yang tidak terduga dan tantrum karena amarah anak yang mudah meledak oleh hal-hal sepele. Hal ini juga tampak dari observasi yang dilakukan peneliti. Satu dari tiga pasang orangtua (tiga ayah dan tiga ibu) memberi hukuman kepada anaknya bila tidak dapat dinasehati dengan cara menguncinya di kamar mandi hingga beberapa saat.

Berdasarkan kondisi tersebut, peneliti menyimpulkan bahwa orang tua umumnya belum mengetahui tentang GPP/H dan bagaimana tindakan yang tepat dalam menangani permasalahan tingkah laku anak GPP/H. Terbatasnya pengetahuan orang tua tentang permasalahan tingkah laku anak dan kemampuan menangani perilaku tersebut menjadikan orang tua rentan mengalami permasalahan terkait dengan anak, seperti kecewa, tertekan, memendam amarah yang kemudian tidak terkontrol sehingga keluar lewat emosi dalam bentuk fisik dan psikis, malu pada orang lain karena perilaku anak, serta perasaan bingung harus bagaimana dalam memberi pengasuhan/ mengarahkan anak. Selain itu orang tua menjadi mudah lelah dan saling menyalahkan atas terjadinya permasalahan tingkah laku anak kepada pasangannya, sehingga hubungan antara ayah dan ibu sebagai orang tua menjadi tidak harmonis. Bukan hanya itu, hubungan orang tua dengan anak juga menjadi kaku, penuh permusuhan yang membuat suasana rumah menjadi kurang nyaman. Apabila hal ini terus berlanjut maka akan dapat menimbulkan dampak yang negatif dalam perkembangan anak di masa depan, khususnya optimalisasi pemenuhan kebutuhan afeksi dan belajar anak dengan GPP/ $\mathrm{H}$.

Penelitian ini dibatasi hanya pada aspek kognitif dalam level pemahaman. Dalam sesi pelatihan dan beberapa pertanyaan dalam wawancara orang tua diminta untuk menjelaskan, mengategorikan, mencirikan, merinci, menguraikan, membedakan, mendiskusikan, mencontohkan, menerangkan, mengemukakan, menyimpulkan, merangkum dan menjabarkan seputar GPP/H dan pengasuhan yang berkualitas. Kata-kata tersebut merupakan kata-kata kerja dalam level pemahaman.

Karakteristik yang paling mendasar pada anak dengan gangguan pemusatan perhatian adalah ketidakmampuannya untuk memusatkan dan mempertahankan perhatian. Sebenarnya bukan tidak memperhatikan tetapi anak memperhatikan segala hal yang ada di sekitarnya. Bagi anak GPP/H, semua stimulus dari luar akan dirasakan dan diterima oleh dirinya sehingga menyebabkan anak sulit menyelesaikan tugasnya (Flick, 1998).

Barkley pada tahun 1987 (dalam Barkley, 2006) merekomendasikan metode parent training untuk anak usia 4-12 tahun. Program pelatihan untuk orang tua anak dengan $\mathrm{GPP} / \mathrm{H}$ yang diuraikan oleh Barkley bersumber dari beberapa pendekatan teoritis dan bukti empiris. Diantaranya adalah Forehand et al.(dalam Barkley, 2006) yang telah berulang kali meneliti anak balita yang dinyatakan memiliki kecenderungan menentang, agresif, dan permasalahan tingkah laku.

Program Barkley berfokus pada proses sosial di dalam keluarga untuk mengembangkan anak dengan GPP/H. Terdapat dua tujuan utama 
dalam program Barkley. Tujuan pertama adalah meletakkan fondasi pengetahuan yang akan mendukung dan meningkatkan keterampilan spesifik yang diajarkan. Tujuan kedua adalah untukmemonitor beragam kemampuan yang telah diperoleh orang tua dari keterampilan majemen anak, yang telah disesuaikan dengan kebutuhan anak-anak dengan GPP/H (Barkley, 2006).

Berkaitan dengan gangguan dalam fungsi keluarga, orang tua yang memiliki anak dengan GPP/H memiliki kesulitan yang lebih besar dibandingkan dengan orang tua yang memiliki anak normal. Persepsi orang tua yang menganggap bahwa anaknya sulit diatur, tidak mau diam mempengaruhi cara orang tua bereaksi terhadap perilaku anak. Orang tua akan memberikan pengasuhan yang berbeda dengan anak lainnya sehingga orang tua akan lebih mengontrol terhadap apapun yang dikerjakan anak, lebih banyak perintah dan larangan, mudah marah, kurang memberikan perhatian terhadap perilaku anak yang positif, dan sering terpancing untuk memberikan hukuman fisik. Orang tua akan memberikan strategi pengasuhan yang memiliki efek berlawanan terhadap apa yang orang tua inginkan dalam menangani permasalahan perilaku anak dengan GPP/H. Hal ini akhirnya meningkatkan stres orang tua, bahkan persepsi orang tua terhadap dirinya sendiri menjadi menurun. Peran dan dukungan orang tua untuk memahami anak GPP/H dan memberikan penanganan yang tepat bagi anak sangat diperlukan yang merupakan bentuk tanggung jawab orang tua dalam pengasuhan anaknya.

Penanganan anak dengan GPP/H biasanya menggunakan pendekatan multidisipliner. Selain menggunakan pengobatan stimulan, juga digunakan berbagai penanganan secara psikologi, seperti pelatihan keterampilan sosial untuk anak, pelatihan manajemen kelas untuk guru, dan pelatihan manajemen perilaku anak bagi orang tua. Mengingat anak menghabiskan waktunya yang paling banyak bersama dengan orang tua, maka keberhasilan program penanganan anak dengan GPP/H tidak lepas dari keterlibatan orang tua. Semakin banyak pengetahuan yang dimiliki oleh orang tua mengenai strategi menangani perilaku anak, maka diharapkan permasalahan perilaku anak dapat diatasi. Disamping meningkatkan pemahaman orang tua mengenai permasalahan anak dengan $\mathrm{GPP} / \mathrm{H}$, manajemen perilaku anak dengan GPP/H diharapkan dapat membantu orang tua dalam meningkatkan kualitas pengasuhannya. Alasan tersebut mendasari mengapa orang tua perlu diberi informasi dan pemahaman untuk menangani permasalahan perilaku anak GPP/H, sehingga membantu penanganan yang dilakukan oleh profesional. Orang tua sering mendapatkan informasi berharga mengenai GPP/H dan manajemen perilaku dalam konteks evaluasi klinis dan konseling. Kedua bentuk ini dapat sukses dalam mendidik orang tua, tetapi memerlukan biaya yang tinggi, dan membutuhkan waktu hingga beberapa bulan, dibanding menggunakan pendekatan secara khusus, seperti pelatihan pengasuhan.

Pelatihan pengasuhan dalam format kelompok merupakan salah satu sarana untuk meningkatkan pengetahuan orang tua tentang GPP/H dan cara menangani perilaku anak dengan GPP/H (Barkley, 2006). Pelatihan pengasuhan yang dikemukakan oleh Barkley pada tahun 1987 (dalam Barkley, 2006) merupakan salah satu bentuk intervensi psikososial yang telah terbukti efektif untuk mengajarkan teknik pengasuhan bagi orang tua yang memiliki anak dengan GPP/H usia 4-12 tahun. Penekanan utamanya adalah mengajarkan cara menerapkan prinsip manajemen perilaku kepada orang tua, oleh karena itu diperlukan kesediaan orang tua untuk mengikuti kegiatan secara menyeluruh. Selain itu, diperlukan kesadaran dalam diri orang tua, bahwa kegiatan yang orang tua ikuti penting untuk menangani permasalahan tingkah laku anak. Kegiatannya meliputi beberapa sesi yaitu memberi gambaran mengenai $\mathrm{GPP} / \mathrm{H}$, 
memahami hubungan orang tua-anak, perhatian positif, menggunakan konsekuensi untuk membentuk target perilaku yang baik, penggunaan time out, mengelola perilaku anak di tempat umum, mengetahui isu seputar permasalahan belajar anak. Peneliti hanyalah sebagai pendamping yang membantu dalam mengarahkan proses belajar, dan memberikan umpan balik selama proses belajar.

\section{METODE PENELITIAN}

Subjek penelitian adalah orang tua, yang terdiri dari ayah dan ibu yang memiliki anak dengan GPP/H taraf sedang dan ringan, serta bersedia mengikuti kegiatan hingga selesai. Jumlah peserta adalah 12 orang (6 Bapak dan 6 Ibu).

Pengumpulan data dalam penelitian ini menggunakan :

1. Skala pemahaman tentang GPP/H dan pengasuhan yang berkualitas.

Tujuan pengukurannya adalah untuk mengukur pemahaman tentang GPP/H dan pengasuhan yang berkualitas pada orang tua. Skala ini disusun sendiri oleh peneliti yang mengacu pada konsep pelatihan pengasuhan untuk anak dengan GPP/H dari Barkley (2006) yang akan diuraikan dalam tabel 1.1. Skala ini terdiri dari 36 pernyataan Benar/Salah.

Tabel 1. Kisi-Kisi Skala Tentang GPP/H dan Pengasuhan Berkualitas Orang Tua

\begin{tabular}{|c|c|c|c|c|c|c|c|}
\hline & $\begin{array}{l}\text { Aspek yang } \\
\text { diungkap }\end{array}$ & No & Faktor & $\begin{array}{l}\text { Nomor Aitem } \\
\text { Favorable }\end{array}$ & $\begin{array}{l}\text { Nomor Aitem } \\
\text { Unfavorable }\end{array}$ & $\begin{array}{l}\text { Jumlah } \\
\text { Per- } \\
\text { Aspek }\end{array}$ & $\begin{array}{l}\text { Jumlah } \\
\text { Total } \\
\text { Seluruh } \\
\text { Aspek }\end{array}$ \\
\hline \multirow[t]{3}{*}{ A. } & $\begin{array}{l}\text { Pemahaman } \\
\text { tentang GPP/H }\end{array}$ & A1 & $\begin{array}{l}\text { Pengetahuan } \\
\text { tentang } \\
\text { karakteristik } \\
\text { GPP/H }\end{array}$ & 2 & 2 & 4 & 12 \\
\hline & & A2 & $\begin{array}{l}\text { Pengetahuan } \\
\text { tentang } \\
\text { penyebab } \\
\text { GPP/H }\end{array}$ & 2 & 2 & 4 & \\
\hline & & A3 & $\begin{array}{l}\text { Pengetahuan } \\
\text { tentang } \\
\text { treatment } \\
\text { GPP/H }\end{array}$ & 2 & 2 & 4 & \\
\hline \multirow{7}{*}{ B. } & $\begin{array}{l}\text { Pemahaman } \\
\text { Tentang } \\
\text { Pengasuhan }\end{array}$ & B1 & $\begin{array}{l}\text { Hubungan } \\
\text { orang tua - } \\
\text { Anak }\end{array}$ & 2 & 2 & 4 & \\
\hline & yang Berkualitas & B2 & $\begin{array}{l}\text { Perhatian } \\
\text { Positif }\end{array}$ & 2 & 2 & 4 & \\
\hline & & B3 & $\begin{array}{l}\text { Penggunaan } \\
\text { Konsekue nsi }\end{array}$ & 2 & 2 & 4 & 24 \\
\hline & & B4 & $\begin{array}{l}\text { Penggunaan } \\
\text { Time Out }\end{array}$ & 2 & 2 & 4 & \\
\hline & & B5 & $\begin{array}{l}\text { Mengelola } \\
\text { Permasalahan } \\
\text { Anak di } \\
\text { Tempat Umum }\end{array}$ & 2 & 2 & 4 & \\
\hline & & B6 & $\begin{array}{l}\text { Permasalahan } \\
\text { Belajar Anak }\end{array}$ & 2 & 2 & 4 & \\
\hline & & & Jumlah & 18 & 18 & 36 & 36 \\
\hline
\end{tabular}


Nilai akan diberikan hanya untuk pemilihan jawaban yang tepat pada setiap nomor soal, dengan ketentuan bahwa nilai 1 diberikan jika jawaban subjek sesuai dengan kunci jawaban, dan nilai 0 akan diberikan jika jawaban subjek tidak sesuai dengan kunci jawaban. Mengingat seluruh soal pada kuesioner ini berjumlah 36, maka skor tertinggi yang dapat dicapai adalah 36 , dan skor terendah adalah 0 .

2. Lembar Observasi

Observasi merupakan metode pengumpulan data penelitian yang dilakukan melalui pengamatan secara langsung terhadap subjek. Setiap perilaku yang dimunculkan oleh subjek dicatat secara sistematis untuk selanjutnya dianalisis bersama data yang lain (Moleong, 2001). Observasi ini dilakukan dengan membuat pedoman observasi yang berisi aspekaspek perilaku subjek, yang dilakukan setiap ada sesi dalam pelatihan. Tujuan pengukuran memberikan gambaran terhadap beberapa aspek yang tampak dari peserta saat sesi diberikan selama pelatihan berlangsung untuk mengetahui bagaimana motivasi diri, respon emosi, wawasan berpikir, kemampuan analisis, komunikasi/ kontak mata, hubungan interpersonal peserta.

3. Metode Wawancara

Metode ini dilakukan untuk mendapatkan data yang lebih akurat tentang kondisi subjek yang tidak dapat terungkap dari metode skala dan observasi. Metode ini digunakan untuk lebih menjelaskan fenomena psikologis yang terjadi dan bersifat kualitatif. Wawancara dilakukan selama pemberian skala pada subjek dengan bentuk wawancara semi terstruktur.

Penelitian ini akan dilakukan dengan pengujian validitas isi (content validity) skala dan modul. Validitas isi pada skala, peneliti ingin melihat apakah alat ukur ini sudah sesuai dan dapat mengukur representasi isi yang tepat, berkaitan dengan relevansi per aitem maupun secara keseluruhan. Sedangkan validitas isi pada modul, peneliti ingin melihat apakah modul yang digunakan sudah sesuai dengan tujuan yang ingin dicapai peneliti. Telaah aitem skala meminta pendapat dari ahli dalam bidangnya (professional judgement) dalam proses telaah aitem maupun dengan melihat apakah aitem-aitem dalam tes itu telah ditulis sesuai kisi-kisi (blue-printnya). Uji coba modul, peneliti juga meminta pendapat dari ahli dalam bidangnya (professional judgement) untuk menganalisis modul apakah sudah sesuai dengan tujuan yang ingin dicapai dan apakah sudah dapat digunakan oleh peneliti untuk memberikan pelatihan kepada orang tua anak prasekolah dengan GPP/H. Menurut Azwar (2000) pengujian validitas isi tidak perlu melalui analisis statistika karena menggunakan analisis rasional.

Penelitian ini dilakukan dengan mengguakan metode eksperimen yaitu dengan Pretest-Posttest Control Group Design dan try-out terpakai. Pengolahan data dilakukan dengan uji statistic Uji Mann-WhitneyWilcoxon dan Uji Kruskal Wallis.

Etika penelitian dilakukan dengan memberikan surat persetujuan (inform consent) sebagai kontrak dengan responden penelitian. Surat perjanjian (inform consent) tersebut berisi hak, kewajiban, aturan-aturan, dan bentuk persetujuan dari responden penelitian untuk ikut serta dan bekerja sama selama penelitian berlangsung. orang tua yang positif mengikuti pelatihan pengasuhan berjumlah 14 orang. Namun, seiring berjalannya waktu penelitian dari pretest, posttest hingga follow-up, ke-14 orang tua yang mengikuti (7 pasang) hanya bertahan 12 orang (6 pasang) saja. Dua orang (1 pasang orang tua) gugur karena sering tidak datang dalam mengikuti pelatihan pengasuhan.. 


\section{HASIL DAN PEMBAHASAN}

Berdasarkan uji validitas aitem pada alat ukur yang dipakai diketahui sejumlah aitem yang gugur.Peneliti menggunakan fasilitas komputer SPSS untuk mendapatkan aitem-aitem yang valid.Setiap item dikatakan valid jika nilai R- hitung $>0$,3. Setelah dilakukan uji coba alat ukur, didapatkan hasil sebagai berikut; skala Pemahaman GPP/H dan manajemen perilaku anak GPP/H terdiri dari 36 aitem, terdapat 22 aitem gugur, sehingga tersisa 14 aitem yang valid. Berdasarkan analisis yang dilakukan didapatkan hasil seperti tampak pada tabel 2 di bawah ini.

Tabel 2. Validitas Aitem Skala Valid dan Tidak Valid

\begin{tabular}{cccc}
\hline Item & R-hitung & Batas & Kriteria \\
\hline item1 & 0,369 & 0,3 & Valid \\
item2 & 0,000 & 0,3 & Tidak Valid \\
item3 & 0,565 & 0,3 & Valid \\
item4 & 0,310 & 0,3 & Valid \\
item5 & $-0,478$ & 0,3 & Tidak Valid \\
item6 & 0,522 & 0,3 & Valid \\
item7 & 0,608 & 0,3 & Valid \\
item8 & 0,546 & 0,3 & Valid \\
item9 & 0,310 & 0,3 & Valid \\
item10 & 0,000 & 0,3 & Tidak Valid \\
item11 & 0,045 & 0,3 & Tidak Valid \\
item12 & $-0,038$ & 0,3 & Tidak Valid \\
item13 & 0,426 & 0,3 & Valid \\
item14 & 0,028 & 0,3 & Tidak Valid \\
item15 & 0,000 & 0,3 & Tidak Valid \\
item16 & 0,426 & 0,3 & Valid \\
item17 & 0,128 & 0,3 & Tidak Valid \\
item18 & 0,296 & 0,3 & Tidak Valid \\
item19 & 0,028 & 0,3 & Tidak Valid \\
item20 & 0,668 & 0,3 & Valid \\
item21 & 0,257 & 0,3 & Tidak Valid \\
item22 & $-0,310$ & 0,3 & Tidak Valid \\
item23 & 0,000 & 0,3 & Tidak Valid \\
item24 & 0,282 & 0,3 & Tidak Valid \\
item25 & 0,546 & 0,3 & Valid \\
item26 & $-0,385$ & 0,3 & Tidak Valid \\
item27 & $-0,192$ & 0,3 & Tidak Valid \\
item28 & 0,371 & 0,3 & Valid \\
item29 & 0,000 & 0,3 & Tidak Valid \\
item30 & $-0,057$ & 0,3 & Tidak Valid \\
item31 & 0,114 & 0,3 & Tidak Valid \\
item32 & 0,565 & 0,3 & Valid \\
item33 & 0,760 & 0,3 & Valid \\
item34 & 0,113 & 0,3 & Tidak Valid \\
item35 & $-0,371$ & 0,3 & Tidak Valid \\
item36 & $-0,296$ & 0,3 & Tidak Valid \\
\hline & & & \\
\hline
\end{tabular}


Berdasarkan keterangan seperti tampak dalam tabel 2, didapatkan hasil bahwa dari keseluruhan item penelitian yang terdiri atas 36 butir angket terdapat 14 item angket yang valid dan dapat digunakan dalam penelitian selanjutnya dengan batas validitas sebesar 0,3 . Hal ini sesuai dengan pendapat yang diutarakan oleh Azwar (2005) yang menyatakan bahwa semua aitem yang mencapai koefisien korelasi minimal 0,30 daya pembedanya dianggap memuaskan. Sedangkan aitem dengan korelasi dibawah 0,30 dapat diinterpretasikan sebagai aitem yang memiliki daya diskriminasi rendah. Butir-butiritem valid tersebut adalah item $1,3,4,6,7,8,9,13$, 16, 20, 25, 28, 32 dan 33. Penyebaran nomor aitem yang valid dan gugur sesuai dengan blue print yang dibuat oleh peneliti, dapat dilihat pada tabel 3 di bawah ini.

Reliabilitas aitem skala yang digunakan oleh peneliti, dapat dilihat dalam tabel 4 seperti tersebut di bawah ini;

Tabel 4. Reliabilitas

\begin{tabular}{ccc}
\hline Cronbach Alpha & Batas & Keterangan \\
\hline 0,796 & 0,7 & Reliabel \\
\hline
\end{tabular}

Tabel 4 diatas menunjukan besarnya nilai reliabilitas dari angket yang digunakan dalam penelitian. Suatu angket/soal dikatakan reliabel

Tabel 3.Penyebaran nomor aitem valid dan gugur pada Skala Pemahaman GPP/H dan Pengasuhan Berkualitas Orang Tua

\begin{tabular}{|c|c|c|c|c|c|c|}
\hline $\begin{array}{l}\text { Aspek yang } \\
\text { Diungkap }\end{array}$ & No & Aspek & $\begin{array}{l}\text { Nomor } \\
\text { aitem valid }\end{array}$ & Jumlah & $\begin{array}{c}\text { Nomor aitem } \\
\text { gugur }\end{array}$ & Jumlah \\
\hline \multirow[t]{4}{*}{$\begin{array}{l}\text { A. Pemahaman } \\
\text { Tentang GPP/H }\end{array}$} & A1 & $\begin{array}{l}\text { Pengetahuan } \\
\text { tentang } \\
\text { karakteristik } \\
\text { GPP/H }\end{array}$ & 4,3 & 2 & 31,34 & 2 \\
\hline & A2 & $\begin{array}{l}\text { Pengetahuan } \\
\text { tentang penyebab } \\
\text { GPP/H }\end{array}$ & 1,32 & 2 & 14,17 & 2 \\
\hline & A3 & $\begin{array}{l}\text { Pengetahuan } \\
\text { tentang treatment } \\
\text { GPP/H }\end{array}$ & 13,20 & 2 & 2,36 & 2 \\
\hline & & Jumlah & & 6 & & 6 \\
\hline \multirow{8}{*}{$\begin{array}{l}\text { B. Pemahaman } \\
\text { Tentang } \\
\text { Penga suhan } \\
\text { yang } \\
\text { Berkualitas }\end{array}$} & B1 & $\begin{array}{l}\text { Hubungan orang } \\
\text { tua - Anak }\end{array}$ & 8,16 & 2 & 5,27 & 2 \\
\hline & B2 & Perhatian Positif & 7,28 & 2 & 10,25 & 2 \\
\hline & B3 & $\begin{array}{l}\text { Penggunaan } \\
\text { Konsekuensi }\end{array}$ & 6 & 1 & $11,23,30$ & 3 \\
\hline & B4 & $\begin{array}{l}\text { Penggunaan Time } \\
\text { Out }\end{array}$ & 33 & 1 & $24,29,35$ & 3 \\
\hline & B5 & $\begin{array}{l}\text { Permasalahan } \\
\text { Anak di Tempat } \\
\text { Umum }\end{array}$ & 25 & 1 & 18, 19, 22 & 3 \\
\hline & B6 & $\begin{array}{l}\text { Permasalahan } \\
\text { Belajar Anak }\end{array}$ & 9 & 1 & $15,21,26$ & 3 \\
\hline & & Jumlah & & 8 & & 16 \\
\hline & & $\begin{array}{l}\text { Jumlah } \\
\text { Keseluruhan }\end{array}$ & & 14 & & 22 \\
\hline
\end{tabular}


jika nilai Cronbach's Alpha yang didapatkan > 0,7 (Stanislaus, 2009). Dari tabel di atas didapatkan nilai Cronbach's Alpha sebesar 0,796 $>0,7$, sehingga dapat dikatakan bahwa aitem-aitem dalam penelitian ini adalah reliabel(dapat dipercaya). kalangan akademisi yang mendalami masalah GPP/H. Semua professional judgement memberikan penilaian sesuai untuk masingmasing kriteria yang menjadi poin pembuatan modul penelitian, dengan prosentase keseluruhan 100\%. Mengacu dari pendapat Riduwan (2008)

Tabel 5. Penilaian Modul

\begin{tabular}{|c|c|c|c|c|c|}
\hline \multirow[b]{2}{*}{$\begin{array}{l}\text { Sub } \\
\text { 3ab }\end{array}$} & \multirow[b]{2}{*}{ Penjabaran Kategori } & \multicolumn{4}{|c|}{ Penilaian Modul } \\
\hline & & Penilai 1 & Penilai 2 & Prosentase (\%) & Kategori \\
\hline 1 & $\begin{array}{l}\text { Kelengkapan dan kejelasan } \\
\text { materi } \\
\text { a. Penjelasan tiap sesi dalam } \\
\text { modul. } \\
\text { b. Lembar observasi, inform } \\
\text { consent, aturan dan } \\
\text { norma-norma kelompok, } \\
\text { evalusi dan lembar } \\
\text { pendukung lainnya. } \\
\text { c. Alat yang digunakan. } \\
\text { d. Lembar kerja. } \\
\text { e. Gambar-gambar } \\
\text { pendukung. }\end{array}$ & Sesuai & Sesuai & 100 & Sangat Baik \\
\hline 2 & Sistematika modul. & Sesuai & Sesuai & 100 & Sangat Baik \\
\hline 3 & $\begin{array}{l}\text { Kesesuain modul dengan } \\
\text { tujuan penelitian. }\end{array}$ & Sesuai & Sesuai & 100 & Sangat Baik \\
\hline 4 & $\begin{array}{l}\text { Kesesuaian bahasa dan isi } \\
\text { modul dengan karakteristik } \\
\text { peserta. }\end{array}$ & Sesuai & Sesuai & 100 & Sangat Baik \\
\hline 5 & $\begin{array}{l}\text { Alokasi waktu yang } \\
\text { digunakan. }\end{array}$ & Sesuai & Sesuai & 100 & Sangat Baik \\
\hline
\end{tabular}

Berdasarkan tabel diatas didapatkan hasil bahwa kesemua sub bab yang digunakan dalam modul penelitian ini memiliki kriteria sangat baik, sesuai dengan penilaian yang diberikan oleh professional judgement. Professional judgementyang memberikan penilaian berjumlah dua orang. Satu orang dari kalangan praktisi (psikolog), dan satu orang lagi adalah dari mengenai penilaian yang diberikan meliputi 5 tingkatan yaitu; 81\% - 100\% Sangat Tinggi, 61\% - 80\% Tinggi, 41\% - 60\% Sedang, 21\% - 40\% Rendah, 0\% - 20\% Sangat Rendah.

Peningkatan pemahaman tentang GPP/H dan pengasuhan yang berkualitas pada orang tua yang memiliki anak GPP/H dapat dilihat secara lebih jelas dalam diagram di bawah ini: 


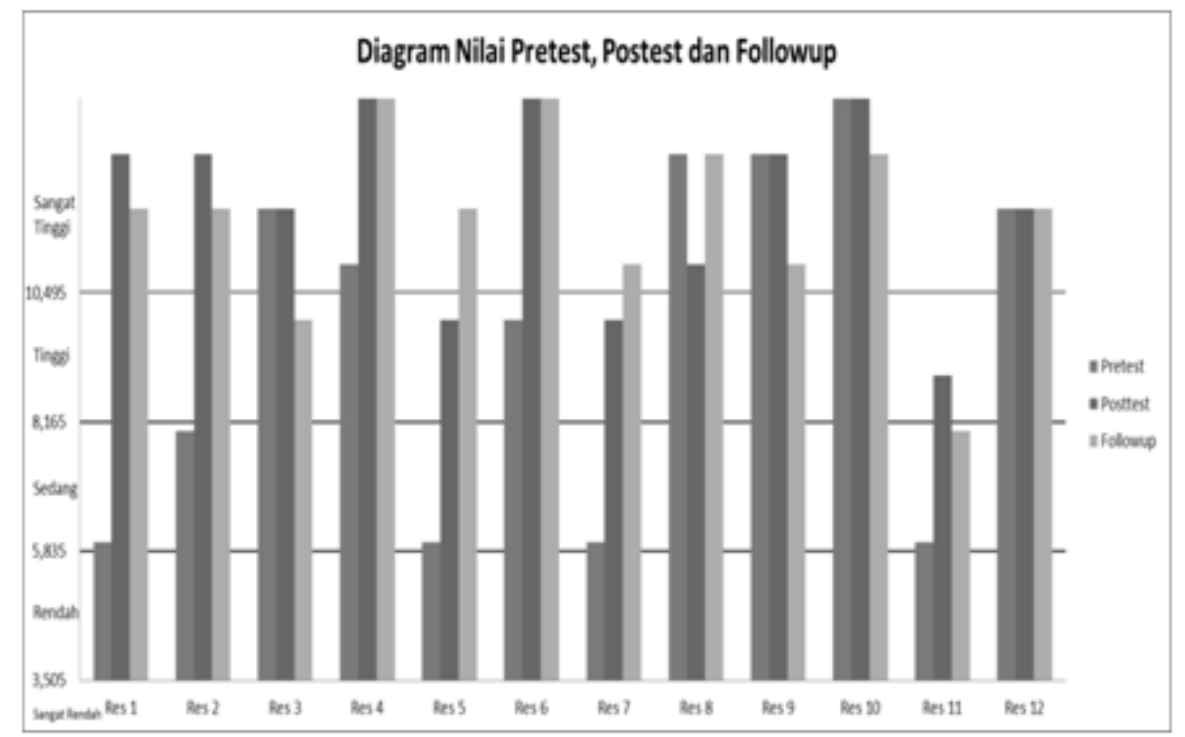

Gambar 1. Diagram batang analisis kuantitatif

Keterangan gambar

Subjek 1-6: Kelompok eksperimen

Kelompok 7-12 : Kelompok kontrol

Jadi, dapat disimpulkan bahwa pada kelompok eksperimen setelah diberikannya pelatihan dari pretest ke posttest terdapat sejumlah peningkatan yang cukup tinggi pada mayoritas subjek penelitian berdasarkan kategori sangat tinggi, yaitu sebanyak tiga sampel. Ini memperlihatkan bahwa terdapat peningkatan pemahaman dan pengasuhan yang berkualitas pada orang tua setelah pelatihan pengasuhan diberikan.

Uji Kruskal Wallis digunakan pada penelitian ini karena pada uji Mann Whitney dan uji Wilcoxon perbedaan nilai signifikansi antara pretest ke posttest, dan posttest ke follow-up pada kelompok eksperimen tidak konsisten hasilnya, sehingga perlu metode yang lebih dapat dipercaya untuk mengolah ketiga data kontinyu tersebut, sehingga dipakai uji Kruskal Wallis untuk menguji hipotesis apakah pelatihan pengasuhan dapat meningkatkan pemahaman tentang GPP/H dan pengasuhan yang berkualitas pada orang tua yang memiliki anak prasekolah dengan GPP/H. Data diuji dengan menggunakan SPSS for Windows versi 15.0 Uji hipotesis dengan menggunakan uji Kruskal Wallis seperti tampak di bawah ini;

Tabel 6. Uji hipotesis dengan uji Kruskal Wallis

\begin{tabular}{lccccc}
\hline \multicolumn{2}{c}{ Variabel } & $\begin{array}{c}\text { Mean } \\
\text { Rank }\end{array}$ & $\begin{array}{c}\text { Chi- } \\
\text { Square }\end{array}$ & Sig & Keterangan \\
\hline \multirow{3}{*}{ Eksperimen } & Pretest & 4,67 & & & \\
& Posttest & 12,50 & 7,811 & 0,020 & Signifikan \\
& Follow-up & 11,30 & & & \\
\multirow{2}{*}{ Kontrol } & Pretest & 9,75 & & Tidak \\
& Posttest & 9,85 & 0,039 & 0,981 & Signifikan \\
& Follow-up & 9,17 & & & \\
\hline
\end{tabular}


Tabel 6. di atas merupakan hasil dari analisis mengunakan uji Kruskal Wallis yang akan digunakan untuk menunjukkan perbandingan antara hasil pretest, posttest dan follow-up pada masing-masing kelompok. Berdasarkan tabel di atas tampak pada variabel eksperimen didapatkan nilai signifikansi sebesar $0,020<0,05$. Hal tersebut menunjukan adanya perbedaan pengaruh antara pretest, posttest dan follow-up, artinya terdapat peningkatan pemahaman tentang GPP/H dan pengasuhan yang berkualitas sebelum dan sesudah hingga program lanjutan diberikan pada subjek yang diberikan perlakuan berupa pelatihan pengasuhan. Mean rank terbesar terdapat pada posttest yaitu sebesar 12,50, mean rank terkecil pada pretest yaitu 4,67, dan pada follow-up sebesar 11,30.

Pada kelompok kontrol didapatkan nilai signifikansi sebesar 0,981 >0,05. Hal tersebut menunjukan tidak adanya perbedaan pengaruh yang nyata antara pretest, posttest dan followup. Artinya adalah tidak terdapat peningkatan pemahaman tentang GPP/H dan pengasuhan yang berkualitas pada Subjek yang tidak diberi perlakuan berupa pelatihan pengasuhan. Mean rank terbesar pada kelompok kontrol terdapat pada posttest, yaitu sebesar 9,85 dan mean rank terkecil terdapat pada followup yaitu sebesar 9,17, pada pretest sebesar 9,75.

Berdasarkan wawancara dan pengolahan data hasil wawancara serta observasi maka diperoleh data sebagai berikut;

Sebagian besar subjek awalnya mempunyai pemahaman tentang GPP/H yang rendah. Banyak yang tidak mengetahui apa itu $\mathrm{GPP} / \mathrm{H}$, sangat sedikit dari yang mengetahui ciriciri/karakteristik anak GPP/H. setelah mengikuti pelatihan pengasuhan subjek penelitian mengenali karakteristik anak GPP/H dengan cara mengenali sendiri perilaku anaknya di rumah dan menambahkan daftar laporan guru di sekolah tentang perilaku anaknya yang berbeda dengan anak lainnya. Beberapa perilaku yang ada pada anak baik di rumah maupun di sekolah adalah; tidak mampu fokus baik saat pelajaran maupun saat bermain, menghindari tugas-tugas/yang memerlukan banyak usaha mental misalnya menghafal dan mengerjakan pekerjaan rumah, sering kehilangan barang-barang misalnya penghapus, pensil, mainan, mudah pindah ke mainan atau tempat lain bila ada suara-suara keras, tidak mendengarkan ketika diajak berbicara, tidak mampu mengikuti instruksi, menampakkan perilaku mengganggu dengan jahil dan usil baik kepada teman maupun adik atau kakak, bicaranya berlebihan, dan sering mengalami kesulitan menunggu giliran, sering kehilangan barang-barang, selalu bergerak, bergerak seperti mesin seolah-olah tidak pernah capek, tidak betah untuk duduk diam dengan tenang selama beberapa saat. Pengetahuan yang subjek tahu tentang GPP/H lebih banyak tentang karakteristik, sedangkan untuk penyebab dan usaha penyembuhan dan pengasuhan masih banyak yang belum memiliki pengetahuan tentang hal tersebut, terlihat dari semua subjek menjawab bahwa penanganan pada anak GPP/H seharusnya dibawa ke psikolog.

Awalnya banyak dari subjek yang merasa ada sesuatu yang tidak wajar dengan anaknya namun tidak mengetahui kenapa anak berperilaku demikian dan sebenarnya ada apa dengan anaknya. Sebagian dari subjek mencari informasi tentang anaknya dari guru di sekolah, sebagian hanya pasrah saja, sebagian yang lain berusaha bertanya dan mengeluhkan masalahnya dengan teman, saudara, atau peergroupnya, dan sebagian yang lain sudah membawanya ke dokter spesialis. Subjek yang kurang usaha dalam mencari informasi tentang kondisi anaknya yang berbeda dengan anak lain, sehingga perilaku anak cenderung menjadi semakin parah.

Reaksi orang tua setelah mendapatkan diagnosis GPP/H untuk anaknya beragam, ada yang merasa sedih, malu, bingung akan masa depan anak, bingung harus bagaimanamenangani anak, bingung harus melangkah dan menerima 
kenyataan, stres, pusing, namun setelah itu banyak yang merasa beruntung karena telah mengetahui dari sekarang sehingga dapat mencari cara untuk menangani permasalahan ini dari sekarang sebelum lebih jauh terlambat. Mengingat usia anak yang masih duduk di bangku prasekolah, sehingga hal ini membuat orang tua merasa lega dan menaruh harapan besar bahwa perilaku anak akan lebih mudah untuk diarahkan dan diperbaiki menjadi lebih baik. Tidak ada satupun dari subjek yang melaporkan bahwa anak diberi obat atas permasalahan ini.

Banyak dari subjek penelitian yang merasa membutuhkan penyelesaian darimasalah perilaku dan emosi dari anaknya yang menyandang GPP/ $\mathrm{H}$ namun tidak tahu harus memulai langkah darimana atas kebingungannya. Beberapa informasi yang didapatkan subjek penelitian dari orang-orang di sekitar, subjek belum mampu menyelesaikan masalah yang ada. Banyak dari subjek mengeluhkan perilaku anak di tempat lain, banyak aduan yang datang dari pihak sekolah bahkan hampir tiap hari yang membuat perasaan orang tua malu, sedih, dan berpikir negatif akan masa depan anaknya yang menyandang GPP/ H. Semua subjek melaporkan merasa kewalahan menghadapi perilaku anak.

Cara dan bentuk pengasuhan yang diberikan kepada anak oleh Subjek beragam, ada yang cenderung membiarkan, menginginkan tidak adanya keributan sehingga mengambil jalan untuk menuruti semua yang diinginkan oleh anak, mencoba bersikap sabar, tetapi sebagian besar masih menggunakan marah sebagai tindakan saat anak tidak bisa dinasehati atau ditegur hingga membuat orang tua jengkel, menangis, dan hilang kesabaran. Sebagian besar subjek masih menggunakan cara-cara yang berbau kekerasan baik fisik maupun psikis, yaitu dengan memukul, mencubit, menylentik, dan sebagian kecil mengunci anak di kamar atau di rumah, mengancam, memarahai anak dengan label anak nakal. Sebagian kecil sudah menggunakan cara- cara positif dengan memeluk, mengelus-ngelus punggung anak, dan memuji. Sebagian kecil subjek mencoba menyalurkan keaktifan anak dengan mengajak anak untuk mengaji/membaca Al-Quran. Dilaporkan oleh orang tua tersebut bahwa mengajak anak mengaji akan membuat anak agak tenang sehingga lebih mudah untuk diberi masukan atau diberi instruksi.

Banyak dari subjek penelitian yang menggunakan kekerasan fisik, ancaman, amarah, dan omelan sebagai senjata untuk mengatasi perilaku anak GPP/H. Sedikit dari orang tua yang menggunakan bentuk perhatian positif untuk mengatasi perilaku anak namun tidak berhasil karena orang tua tidak konsisten dalam menerapkan bentuk pengasuhan yang diterapkan. Banyak subjek mangatakan bahwa antara subjek dan pasangan sering tidak sepaham dalam memberikan pengasuhan kepada anak.

Sebagian besar, terutama bapak menyerahkan kepada ibu atas semua permasalahan yang berhubungan dengan pengasuhan. Sementara itu, Subjek ibu merasakan stres, kesal, capek, emosi, bahkan hampir depresi atas permasalahan sehari-hari dari anak, ditambah dengan penyerahan tanggung jawab pengasuhan dari bapak kepada ibu semakin membuat ibu bingung harus bagaimana dan melakukan tindakan apa.

\section{SIMPULAN}

Berdasarkan hasil penelitian dapat disimpulkan bahwa;

1. Pelatihan pengasuhan secara signifikan meningkatkan pemahaman tentang GPP/H pada orang tua yang mempunyai anak prasekolah dengan GPPH.

2. Pelatihan pengasuhan secara signifikan meningkatkan pemahaman tentang pengasuhan yang berkualitas pada orang tua yang mempunyai anak prasekolah dengan GPP/H. 


\section{DAFTAR PUSTAKA}

Azwar, S. (2000).Penyusunan Skala Psikologi. Yogyakarta : Pustaka Pelajar.

Azwar, S. (2005).Reliabilitas dan Validitas.Yogyakarta : Pustaka Pelajar.

Barkley, R A. (2006).Attention Deficit Hyperactivity Disorder. A Handbook for Diagnosis and Treatment.3nd Edition. New York : The Guilford Press.

Briesmeister, J M. \& Schaefer, C. E.(1995). Handbook Of Parent Training.USA : John Wiley \& Sons Inc.

Flanagan, R (2005). ADHD Kids. Attention Deficit Hyperaction Disorder. Jakarta: Prestasi Pustaka Publisher.

Flick, U. (1998). Everyday knowledge in social psychology. In U. Flick (Ed.), The psychology of the social (pp. 41-69). New York: Cambridge University Press.

Grad L. Flick (1998) ADD/ADHD Behavior_Change Resource Kit, The Center For Applied Research in Education, New York.
Gromisch, Stannard E. (2013). Helping Your Kids Keep Organized with Childhood ADHD.Psych Central. Retrieved on February 23, 2014, from http:// psychcentral.com/lib/helping-yourkids-keep-organized-with-childhoodadhd/00017181

Moleong, Lexy J., (2001). Metode Penelitian Kualitatif. Cetakan XIV. Jakarta : Remaja Rosdakarya.

Pentecost, D. (2004). Menjadi Orang Tua Anak $A D D / A D H D$, Tidak sanggup? Tidak Mau? Penerjemah Yayasan Suryakanti. Jakarta : Dian Rakyat.

Riduwan (2008). Belajar Mudah Penelitian Untuk Guru, Karyawan dan Peneliti. Alfabeta.

Uyanto, Stanislaus S. (2009), Pedoman Analisis Data dengan SPSS, Edisi 3, Grha Ilmu, Yogyakarta. 
